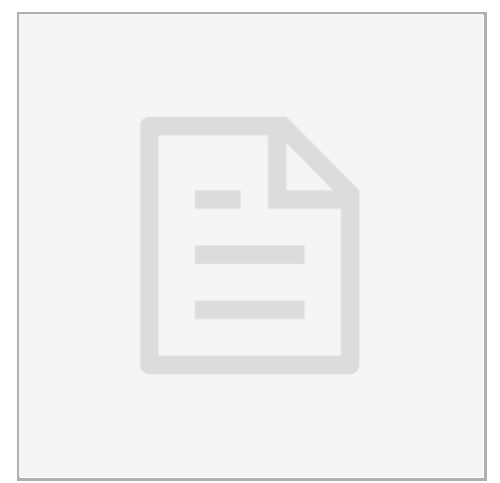

JAN 08, 2020

\section{open $\boldsymbol{\odot}$ access}

DOI:

dx.doi.org/10.17504/protocol s.io.8tvhwn6

Protocol Citation: Carter Palmer, Christine Liu, Jerold Chun 2020. Nuclei Isolation for SNARE-seq2 . protocols.io https://dx.doi.org/10.17504/p rotocols.io.8tvhwn6

License: This is an open access protocol distributed under the terms of the Creative Commons Attribution License, which permits unrestricted use, distribution, and reproduction in any medium, provided the original author and source are credited

Protocol status: Working We use this protocol and it's working

Created: Oct 28, 2019

Last Modified: Jan 08, 2020

PROTOCOL integer ID: 29269

Keywords: Brain, Nuclei, Isolation, Single-Cell

\section{(3) Nuclei Isolation for SNARE-seq2}

\section{Carter Palmer ${ }^{1}$, Christine Liü ${ }^{1}$, Jerold Chun²}

${ }^{1}$ University of California, San Diego, and Sanford Burnham Prebys Medical Discovery Institute;

${ }^{2}$ Sanford Burnham Prebys Medical Discovery Institute

\section{BICCN}<smiles></smiles>

\section{Carter Palmer}

\section{ABSTRACT}

This protocol is intended to be used for the isolation of nuclei from fresh-frozen brain tissue in preparation for analysis by Single-Nucleus Chromatin Accessibility and mRNA Expression sequencing (SNARE-seq). It has been applied to tissues from mouse, marmoset, and human.

\section{GUIDELINES}

This protocol is designed specifically for isolating tissue for SNARE-seq. RNA stability is considered at every step. Samples are kept on ice throughout the process, all centrifuges are pre-chilled to $4{ }^{\circ} \mathrm{C}$ before use, and RNase Away is used to spray down all surfaces and pipets before use. 
MATERIALS

MATERIALS

88 Sucrose Fisher Scientific Catalog \#S3-212

88 Protease Inhibitor Tablets cOmplete Mini EDTA free Roche Catalog

\#11836170001

88 RNase Inhibitor Takara Catalog \#2313A

88 Bovine Serum Albumin Gemini Bio-Products Catalog \#700-107P

88 Magnesium acetate tetrahydrate Sigma-aldrich Catalog \#M5661

$\$ 8$ Calcium chloride dihydrate Sigma Aldrich Catalog \#C5080

88 Ethylenediaminetetraacetic acid (EDTA) Sigma Aldrich Catalog \#EDS

88 Triton X-100 Sigma Aldrich Catalog \#T8787

88 16\% Formaldehyde (w/v) Methanol-free Thermo Fisher Scientific Catalog \#28906

88 DAPI Sigma Aldrich Catalog \#10236276001

88 50um filters Sysmex Catalog \#04-0042-2317

82 Tissue Homogenizer Contributed by users Catalog \#358005

\section{Buffer Preparation}

Nuclei Extraction Buffer (NEB):

\begin{tabular}{|l|l|l|l|l|}
\hline & $\begin{array}{l}\text { Final } \\
\text { Concentra } \\
\text { tion }\end{array}$ & $\begin{array}{l}\text { Chemical } \\
\text { to Add }\end{array}$ & $\begin{array}{l}\text { Stock } \\
\text { Concentra } \\
\text { tion }\end{array}$ \\
\hline Sucrose & $320 \mathrm{mM}$ & & $5.48 \mathrm{~g}$ & Solid \\
\hline $\begin{array}{l}\text { Magnesium } \\
\text { Acetate }\end{array}$ & $3 \mathrm{mM}$ & & $32.16 \mathrm{mg}$ & Solid \\
\hline $\mathrm{CaCl} 2$ & $5 \mathrm{mM}$ & & $50 \mu \mathrm{l}$ & $5 \mathrm{M}$ Stock \\
\hline EDTA & $100 \mu \mathrm{M}$ & & $10 \mu \mathrm{l}$ & $\begin{array}{l}0.5 \mathrm{M} \\
\text { Stock }\end{array}$ \\
\hline Tris-HCl pH 8 & $10 \mathrm{mM}$ & & $500 \mu \mathrm{l}$ & $1 \mathrm{M}$ Stock \\
\hline Triton X-100 & $0.1 \%$ & & $500 \mu \mathrm{l}$ & $\begin{array}{l}10 \% \\
\text { Stock }\end{array}$ \\
\hline MilliQ Water & & & $\begin{array}{c}\text { Bring to } \\
50 \mathrm{ml}\end{array}$ & \\
\hline $\begin{array}{l}\text { RNase } \\
\text { Inhibitor }\end{array}$ & $80 \mathrm{U} / \mathrm{ml}$ & & $100 \mu \mathrm{l}$ & $\begin{array}{l}40,000 \mathrm{~m} / \\
\mathrm{ml}\end{array}$ \\
\hline $\begin{array}{l}\text { Protease } \\
\text { Inhibitor Tablet }\end{array}$ & & & 1 Tablet & \\
\hline
\end{tabular}


Prepare NEB as outlined above. $50 \mathrm{ml}$ is enough for 3 samples. Combine reagents 2-8 the night before nuclei isolation and chill at $4{ }^{\circ} \mathrm{C}$. Add RNase inhibitor and Protease Inhibitor tablet the morning of isolation.

2 PBSE + Sucrose:

\begin{tabular}{|l|l|l|l|l|}
\hline & $\begin{array}{l}\text { Final } \\
\text { Concentra } \\
\text { tion }\end{array}$ & & $\begin{array}{l}\text { Chemical } \\
\text { to Add }\end{array}$ & $\begin{array}{l}\text { Stock } \\
\text { Concentra } \\
\text { tion }\end{array}$ \\
\hline Sucrose & $320 \mathrm{mM}$ & & $5.48 \mathrm{~g}$ & Solid \\
\hline EGTA & $250 \mu \mathrm{M}$ & & $25 \mu \mathrm{l}$ & $0.5 \mathrm{M}$ \\
\hline $\begin{array}{l}1 \times \mathrm{PBS} \mathrm{pH} \\
7.4\end{array}$ & & & $\begin{array}{l}\text { Bring to } \\
50 \mathrm{ml}\end{array}$ & \\
\hline $\begin{array}{l}\text { RNase } \\
\text { Inhibitor }\end{array}$ & $40 \mathrm{U} / \mathrm{ml}$ & & $50 \mu \mathrm{l}$ & $\begin{array}{l}40,000 \mathrm{U} / \\
\mathrm{ml}\end{array}$ \\
\hline $\begin{array}{l}\text { Protease } \\
\text { Inhibitor } \\
\text { Tablet }\end{array}$ & & & 1 Tablet & \\
\hline
\end{tabular}

Prepare PBSE + Sucrose as outlined above. $50 \mathrm{ml}$ is enough for 3 samples. Combine reagents 24 the night before nuclei isolation and chill at $4{ }^{\circ} \mathrm{C}$. Add RNase inhibitor and Protease inhibitor tablet the morning of isolation.

\section{PBSE + BSA:}

\begin{tabular}{|l|l|l|l|l|}
\hline & $\begin{array}{l}\text { Final } \\
\text { Concentra } \\
\text { tion }\end{array}$ & & $\begin{array}{l}\text { Chemical } \\
\text { to Add }\end{array}$ & $\begin{array}{l}\text { Stock } \\
\text { Concentra } \\
\text { tion }\end{array}$ \\
\hline BSA & $1 \%$ & & $500 \mathrm{mg}$ & Solid \\
\hline EGTA & $250 \mu \mathrm{M}$ & & $25 \mu \mathrm{l}$ & $0.5 \mathrm{M}$ \\
\hline $\begin{array}{l}1 \times \mathrm{PBS} p \mathrm{H} \\
7.4\end{array}$ & & & $\begin{array}{l}\text { Bring to } \\
50 \mathrm{ml}\end{array}$ & \\
\hline $\begin{array}{l}\text { RNase } \\
\text { Inhibitor }\end{array}$ & $40 \mathrm{U} / \mathrm{ml}$ & & $50 \mu \mathrm{l}$ & $\begin{array}{l}40,000 \mathrm{U} / \\
\mathrm{ml}\end{array}$ \\
\hline $\begin{array}{l}\text { Protease } \\
\text { Inhibitor } \\
\text { Tablet }\end{array}$ & & & 1 Tablet & \\
\hline
\end{tabular}

Prepare PBSE + BSA as outlined above. $50 \mathrm{ml}$ is enough for 3 samples. Combine reagents 2-4 the night before nuclei isolation and chill at $4{ }^{\circ} \mathrm{C}$. Add RNase inhibitor and Protease inhibitor tablet the morning of isolation. 


\section{Tissue Dissociation}

4 Remove tissue from $-80^{\circ} \mathrm{C}$ storage and place on ice.

5 Image the tissue rapidly in front of a ruler

6 Add $1 \mathrm{ml}$ of ice cold NEB to the tissue and incubate on ice for $00: 15: 00$

7 During the incubation, wash the homogenizer with MilliQ water, $10 \%$ bleach, $70 \% \mathrm{EtOH}$, and MilliQ water again

8 Rinse homogenizer with $1 \mathrm{ml}$ of ice cold NEB

9 Once the incubation is complete, add $1 \mathrm{ml}$ of fresh NEB to the homogenizer and transfer the tissue and the $1 \mathrm{ml}$ of NEB it is in to the homogenizer

10 Homogenize the tissue using 20 compressions with the pestle, or until the tissue is entirely dissociated, this step can be variable

11 Pass nuclei suspension through 50 micron filter into a $15 \mathrm{ml}$ conical tube, wash filter with another $4 \mathrm{ml}$ of NEB 
12 Wait for 00:05:00

13 Centrifuge the samples $\because 8820 \times \mathrm{g}, 5 \mathrm{~min}$

14 Carefully aspirate the supernatant and slowly resuspend the pellet in $1 \mathrm{ml}$ of NEB

15 Gently add another $9 \mathrm{ml}$ of NEB to the sample

16 Centrifuge the samples $\because 820 \times \mathrm{g}, 5 \mathrm{~min}$

\section{Nuclei Fixation}

17 Aspirate the supernatant and slowly resuspend the samples in $1 \mathrm{ml}$ of PBSE + Sucrose

18 Gently add another $5 \mathrm{ml}$ of PBSE + Sucrose

19 Centrifuge the samples $\because 820 \times \mathrm{g}, 5 \mathrm{~min}$ 
20 Aspirate all but approximately $\triangle 100 \mu \mathrm{L}$ of the PBSE+Sucrose, and gently resuspend the nuclei pellet in the remaining volume

21 While gently vortexing, add $5 \mathrm{ml}$ of $0.5 \%$ Formaldehyde diluted in 1 X PBS

$22 \quad$ Fix for 10 min on ice

23 Centrifuge the samples $\because: 820 \times \mathrm{g}, 5 \mathrm{~min}$

24 Aspirate the supernatant and slowly resuspend the samples in $1 \mathrm{ml}$ of PBSE + Sucrose

25 Centrifuge the samples $\because 820 \times \mathrm{g}, 5 \mathrm{~min}$

\section{DAPI Staining and Sorting}

26 Aspirate the supernatant and slowly resuspend the samples in $1 \mathrm{ml}$ of PBSE + BSA

27 Gently add another $10 \mathrm{ml}$ of PBSE + BSA 
$28 \quad$ Centrifuge the samples $\because 820 \times \mathrm{g}, 5 \mathrm{~min}$

29 Make $1 \mathrm{ml} /$ sample of PBSE + BSA + DAPI by adding DAPI at a final concentration of $1.25 \mu \mathrm{g} / \mathrm{ml}$ to PBSE + BSA. This is a 1:4000 dilution from a DAPI stock at $5 \mathrm{mg} / \mathrm{ml}$

30 Aspirate the supernatant and slowly resuspend the samples in $1 \mathrm{ml}$ of PBSE + BSA + DAPI

31 Pass nuclei suspension through 50 micron filter into a FACS tube, gently tap on table to get all nuclei through the filter

32 Use the DAPI singlet peak to sort singlet nuclei events into a $2 \mathrm{ml}$ low binding eppendorf tube.

33 Store all samples on ice until SNARE-seq processing begins. Do not store for longer 4 hours before processing. 